\title{
The Trans-Border Arrangement of Ming Pilgrim Flasks and the Narrative of Transculturation in the British Museum
}

\author{
Pao-Yi Yang
}

\begin{abstract}
This article revolves around the concepts of trans-border arrangement and transculturation and their significance to a critical theme in the British Museum today: cultural connectivity. Trans-border arrangement refers to displaying and classifying an object in museum space based on the object's context of production as well as its relations with other objects and people; its transfer, gifting, collection, consumption, and appropriation. It represents, in museum space today, the circulation of material objects across cultural-geographical boundaries over a period of time in the past. To illustrate a trans-border arrangement, this article provides an empirical investigation of the multiple placements of Ming pilgrim flasks in the British Museum's galleries of China, India, and Europe. This display scheme not only shows how the British Museum can accommodate the narrative of transculturation into its spatial configuration, but also how the institution of the museum can engage in the global turn in art history that blossomed in the late 1990s.
\end{abstract}

Key words: Transculturation, Trans-border arrangement, Object biographies, Ming pilgrim flasks, British Museum

\section{Introduction}

Since 2017, the British Museum has undertaken a significant transformation in its narrative scheme. According to the museum director, Hartwig Fischer (appointed in 2016), this transformation will last for a decade and pivot on a rethinking of the spatial planning of galleries:

Our vision will be to create a museum which tells more coherent and compelling stories of the cultures and artefacts we display to allow comparisons to be made across cultures and timeframes. [...] This will involve a new narrative for the collections, an emphasis on the interconnectedness of cultures...1

So, how exactly does the museum make its narrative structure and spatial organization more coherent to better express the 'interconnectedness of cultures'? For Fischer, this goal means that the museum needs to deploy and interpret its objects not only based on their places of origin but also the context of cultural exchange across regions. ${ }^{2}$ As an initial result of the transformation plan, the new Gallery 33 China and South Asia (opened in November 2017) displays Chinese and Indian objects and incorporates products from Japan, Europe, and West Asia to amplify a sense of cultural connectivity and diversity. Indeed, in the British Museum, which boasts encyclopedic collections, walking through galleries delineated according to regional/continental boundaries provides a space to discuss cultural connections embodied in material objects that have circulated through different places. As the museum has begun to re-display objects in an attempt to loosen predetermined boundaries between cultures, it seems pertinent to explore how such a display scheme, which I call trans-border arrangement, transforms the narrative presented in the physical layout of the museum.

The article proceeds as follows. The first part draws upon the concepts of social/ global lives of things and transculturation to gain an insight into a trans-border arrangement 
in the British Museum today. The second part illustrates this display scheme through a close reading of the museum's trans-border arrangement of Chinese blue-and-white pilgrim flasks of the Ming dynasty (1368-1644). The pilgrim flask, as a category of Chinese porcelain, is characterized by a flattened globular body with a cylindrical neck. In China, such porcelain vessels are also known as bao yue ping 抱月瓶 [moon flasks] or bianhu 扁竹 [flattened bottles]. Ming pilgrim flasks are a potent example to explore how trans-border arrangement is relevant to rethinking the existing regionally-bounded categorization in the museum, because they were produced by cultural connections and for global markets. The Ming pilgrim flasks are found in the European gallery and the newly renovated gallery of China and South Asia, echoing these flasks' movements across Ming China, Mughal India (1526-1857), and Europe via diplomatic and commercial channels between the fifteenth and the seventeenth centuries. The final part of this article contextualizes the museum's trans-border arrangement of Ming flasks in terms of the global turn in art history that blossomed in the late $1990 \mathrm{~s}^{3}$

\section{Trans-Border Arrangement in a Transcultural Perspective}

The power of cultural boundaries has been challenged by a number of studies looking for a more reciprocal relationship between museums and the communities around them (PoovayaSmith 1998; Macdonald 2003; Beier-de Haan 2006; Mason 2013). To this end, thematic frameworks are generally considered as a useful model of museum categorization to replace territorial schemes, as they can 'cut across geographical and traditional "community" identities' (Macdonald 2003: 8). However, in addressing the question of 'how the identity potentialities of the museum can be put to new use', the dominant, cultural-geographical categories do not have to be entirely abolished (Macdonald 2003: 8). As the art historian Mary Sheriff has pointed out, such divisions, which structure most museum galleries and art-historical narratives, 'are surely heuristic necessities' (Sheriff 2010: 1). This is especially true in the case of the British Museum; for a museum that presents an extensive collection, a culturalgeographical framework allows visitors to navigate the gallery space easily. The point here is to acknowledge that these boundaries are not mutually exclusive but porous and traversable, and museums can spatialize material circulations that transcend the existing borderlines by exploring the transformative impact of the trans-border movements of the objects they display.

Trans-border arrangement refers to displaying and classifying an object not only based on its context of production, but also other biographical contexts related to its mobile trajectories; its transfer, gifting, collection, consumption, and appropriation. This display scheme represents, in museum space today, the circulation of material objects across territorial boundaries over a period of time in the past. The prefix 'trans-' in a trans-border arrangement means traversal and transformation; it highlights the transformation of meaning and identity of objects along their movements across cultural boundaries. Trans-border arrangement, as a display scheme that the British Museum has begun to put into practice, echoes the art historians Monica Juneja and Anna Grasskamp's (2018) call for a critical curatorial and pedagogical practice that helps articulate objects' meanings in a dynamic process of displacement and integration from one cultural context to another. Juneja and Grasskamp urge a rethink of the validity of conventional categories, such as nation-states, regions, and period styles that are prevalent in the discipline of art history and the institution of the museum. They propose to develop new modes of display and interpretation that allow 'a polyphonous object to narrate its many stories', instead of being anchored in 'a self-contained geographical location [and thus freezing its] identity within a myth of origins' (Juneja and Grasskamp 2018: 4). This mode of curating, as Juneja and Grasskamp note, lies at a critical intersection between the spatial organization of museum collections and the concept of material objects' social/global biographies (Juneja and Grasskamp 2018: 4-7).

According to the anthropological concept of object biographies, the objects' meanings are contextual, accumulated, and flux, rather than inherent, monolithic, and fixed. In the landmark volume The Social Life of Things (1986), the the anthropologists Arjun Appadurai and Igor Kopytoff point out that things, like people, have social lives. Their biographical approach seeks to understand objects' meanings in terms of their life cycles 'from production, through exchange/distribution, to consumption' (Appadurai 1986: 13, 18; Kopytoff 1986: 66-8). Taking 
up the idea of the social lives of things, the historians Anne Gerritsen and Giorgio Riello further explore things' global lives, following the global turn in the field of history, in which 'the connected histories that led to the circulation of objects throughout the various parts of the world' are brought to the fore (Gerritsen and Riello 2016: 13). This approach emphasizes circulation and re-contextualization on a global scale to see how objects acquire multiple meanings and identities as they travel across regions. It helps navigate the tension between the sense of cultural compartmentalization suggested in the British Museum's spatial organization (the museum's main galleries are divided by region) and the museum's objects that have global trajectories and biographies (e.g. Ming pilgrim flasks). A biographical perspective, as Juneja and Grasskamp have emphasized, enables a shift of focus 'from the site of origin of an object - the place where traditional art history situates and interprets its objects - to more interactive zones and spaces of contact in order to look at the dynamic relationships between a number of sites' (Juneja and Grasskamp 2018: 7). Through the trans-border arrangement of objects, the British Museum's space can become such an 'interactive zone', in which the global circulation of objects and historical interactions between cultures are presented.

The conception of the social lives of things has been incorporated in studies of museum exhibitions to reconstruct historical developments and see how objects have been imbued with multiple meanings by collectors and exhibition makers before and after they enter museums (Gosden and Marshall 1999; Alberti 2005; Hill 2012). These studies often aim to encourage more dynamic ways of configuring collections that can recall their life cycles and the public/social issues behind them, or show how individual (e.g. collectors) and institutional biographies are involved in the process of meaning making. Nevertheless, they barely address the question of how the process in which an object gains layers of meanings and identities in its displacements across cultural-geographical boundaries can be reenacted in museum space. This question is the focus of the present article.

The trans-border arrangement of objects in the British Museum enables one to conceive of cultural boundaries (which roughly overlap with the museum's departmental boundaries) as porous. This display scheme maps out the narrative of transculturation in the museum space; a space that is both a material container wherein objects are laid out, and a discursive medium whereby a given narrative and ideological setting is constructed and communicated (Bennett 1995). ${ }^{4}$ The term 'transculturation' was coined in 1940 by the anthropologist Fernando Ortiz as an alternative to the more Eurocentric term acculturation (Ortiz 1970[1940]: viii). According to Ortiz, the idea of acculturation has a Eurocentric stance. It suggests that immigrants and indigenous people have to acculturate themselves to the superior Western culture. For Ortiz, acculturation suggests a unilateral process of acquisition and adaption. Comparatively, transculturation better expresses the diverse transformations and repercussions that occurred 'in the different phases of the process of transition from one culture to another' (Ortiz 1970[1940]: 102). ${ }^{5}$ Later, in the early twenty-first century, the philosopher Wolfgang Welsch $(1999,2001)$ reconfigures the concept of transculturation/transculturality in order to dismantle the Enlightenment idea of culture as a bounded and homogeneous sphere. In the lens of modern societies, Welsch argues that a monolithic idea of culture is untenable, in that 'Cultures today are extremely interconnected and entangled with each other. Lifestyles no longer end at the borders of national cultures, but go beyond these, are found in the same way in other cultures' (Welsch 2001: 68). With Welsch, transculturality moves beyond the ideas of multiculturality and interculturality by highlighting the 'multi-meshed and inclusive' quality of today's cultures; the term avoids the pitfall of presupposing a 'sphere-like constitution of cultures' (Welsch 2001: 66, 77).

Welsch's critique of a bounded notion of culture helps reflect on the dominant modes of museum categorization based on a cultural division. Nevertheless, this article departs from his understanding of transculturation in two ways. First, Welsch takes a somewhat restricted view of transculturation. His concept pertains specifically to modern societies following the wave of globalization, and so it excludes a historical perspective. Welsch is concerned more about how the concept of transculturation can be used to understand the features and forms of cultures today, so as to correct ideas of cultural exclusiveness generated in ethnocentric frameworks of belonging. As such, his notion of transculturation is not so germane to my examination of the display of the history of material culture in the British Museum, given that 
most of the museum's collections were gathered in earlier historical epochs. Second, and more importantly, Welsch considers transculturation as a static cultural trait, without explicitly accounting for the dynamic processes of transformation within the circuit of exchange. ${ }^{6}$ This obviously contradicts my focus here on the trans-border movements of objects. In view of these two factors, this article draws on the art historian Monica Juneja's position on the notion of transculturation.

Instead of designating border-crossing and cultural mixing as exclusive to modern societies, Monica Juneja proposes to 'go back to Antiquity and extend [the research lens] into the present in order to understand historical forms of mobility.' J Juneja refers to transculturation as both 'a concrete object of investigation as well as an analytic method', and conceives of a transcultural perspective that challenges the existing narratives of cultural solidarity and signals a view of culture that highlights 'contact, interaction and entanglement' (Juneja and Kravagna 2013: 24-5). In this view, boundaries between cultures are not a given but rather constitute a subject of analysis. A transcultural framework of analysis enables an intensive engagement with questions of 'different kinds of relationships between actors, objects and cultural groups which follow from encounter and mobility'. ${ }^{8}$ Indeed, as this article attempts to show, the trans-border arrangement of Ming pilgrim flasks in the galleries of China, India, and Europe in the British Museum today does not only reenact the objects' spatial mobility across boundaries between cultures and regions. It also describes various relationships between the objects and people of different cultural groups who produced, customized, owned, transferred, and appropriated them.

Additionally, this article is grounded in Monica Juneja's transculturation concept because she draws on transcultural thinking to critically revisit the existing frameworks of museum categorization (Juneja 2018: 478-80). The recent years have seen the burgeoning of a transculturally framed art history that sought to, as Juneja notes, "use connected material cultures to unsettle many narratives of style and civilizational uniqueness, in scholarship as well as in the expanding world of curation and display' (Juneja 2018: 469). ${ }^{9}$ In the service of museum categorization, a transcultural perspective enables a re-anchoring of an institution's collection pieces: a way to categorize and display objects not solely in line with national/ regional/continental boundaries and the perspective of production, but which moves beyond these boundaries to unmask 'the palimpsestic identities' of certain objects (Juneja 2018: 479). Below, I will illustrate the British Museum's potentiality to incorporate a transcultural perspective in its narrative with the trans-border arrangement of three Ming pilgrim flasks across Gallery 33 China and South Asia and Gallery 46 Europe 1400-1800, along with a Chinese-style Iranian flask in Gallery 43 The Islamic World. ${ }^{10}$

\section{Objects in Motion: The Trans-Border Arrangement of Ming Pilgrim Flasks in the British Museum}

As indicated by the word 'pilgrim' itself, Ming pilgrim flasks are 'objects in motion' (Martin and Bleichmar 2015). Their globular-shaped body can be traced back to the eastern Mediterranean in the Late Bronze Age (Leidy 2015: 74). Later, metal and glass pilgrim flasks became relatively common in West Asia. In the British Museum, examples of pottery from the eastern Mediterranean can be found in Gallery 57 Ancient Levant, and pieces of metal and glass flasks are seen in Galleries 42-43 The Islamic World. Pilgrim flasks were introduced to Tang China (618-907) via the Silk Roads (Finlay 1998: 181). A Tang ceramic flask decorated with scrolling grapevines (museum number: 1936,1012.243) is showcased in Gallery 33 China and South Asia, with its shape and decoration labelled as 'exotic'. ${ }^{11}$ With travellers, envoys, and merchants, pilgrim flasks had traversed vast cultural and geographical distances before Ming flasks were made in China, from where their journey towards Iran, India, and Europe began (Finlay 2010: 299-300). In Safavid Iran (1501-1736), in particular, the blue-and-white colour scheme and floral decorations on Ming porcelain were appropriated by Iranian potters to make their pilgrim flasks appear Ming-like. Thus, we see that a circuit of exchange ran between Ming China and Safavid Iran. This connection will be explained further by associating a Ming pilgrim flask in Gallery 33 China and South Asia (museum number: 1947,0712.325) with a Chinese-style Iranian flask in Gallery 43 The Islamic World (museum number: 1950,1019.1). ${ }^{12}$ 
Both galleries underwent a major refurbishment that aimed to reinforce the connectedness of cultures, and reopened in 2017 and 2018, respectively. ${ }^{13}$

Gallery 33 contains two sections, China and South Asia, both employing a largely chronological framework, spanning prehistory to modern times. Each section shows a blueand-white Ming pilgrim flask with paired ruyi handles. The one displayed in the bay Early Ming 1368-1487 in the Chinese section is decorated with fruiting and flowering lychee branches (Yongle period, 1403-24; museum number: 1947,0712.325), while the one placed in the bay Sultans and Mughals 1300-1850 in the South Asian section is ornamented with blossoming peony branches (Yongle or Xuande period, 1403-35; museum number: 1968,0422.32). ${ }^{14}$ They were both made in the imperial kilns at Jingdezhen during the first half of the fifteenth century, and together they materialize the extensive trade networks between Ming China and Mughal India. When considered individually, these two pilgrim flasks are components of the museum's chronological presentation of Chinese and Indian material culture. But when considered together, they demonstrate the museum's potential to accommodate transcultural biographies of objects in its spatial configuration.

In the Chinese section of Gallery 33, the Ming pilgrim flask is displayed in the showcase Trade and Diplomacy. The showcase presents interregional connections and exchanges of materials and visual languages. Its theme revolves around seven Ming government-backed voyages to South and West Asia between 1405 and $1433 . .^{15}$ Thus, we see Chinese red lacquerware gifted to the Japanese Ashikaga court (1336-1573) combined with Japanese blades gifted to the Ming court; a Ming dish grouped with a Vietnamese stoneware plate with a similar colour scheme and decoration; a pair of Ming pillow ends inlaid with gems from India and Sri Lanka; and a Ming pilgrim flask juxtaposed against two other Ming bottles and two comparable pieces of metalwork made in Herat, which shows the '[Ming] Court fashion for the exotic', according to the label. Adjacent to the display, reproductions of Horse with Chinese Grooms (1418) and Royal Feast in a Garden (about 1444, depicting vessels, some presumably Chinese blue and white porcelain) illustrate a reciprocal exchange: large horses from the Middle East were vital for the Ming army, and Ming porcelain was desirable for the Persian Sultans. ${ }^{16}$ These graphics help create a transition between Gallery 33 China and South Asia and Galleries 42-43 The Islamic World, where several pieces of Ming porcelain are grouped with Persian ceramics.

Influenced by shapes found in Islamic design, pilgrim flasks were exotic in the context of the Ming empire. Yet, when Ming porcelain became famous in the Islamic markets, Iranian artisans started to fashion their exotic-looking stone-paste flasks by imitating the visual designs of Ming porcelain. This connection is shown by the showcase Chinese Inspirations in Gallery 43 The Islamic World. Here, a Ming-style, blue-and-white Safavid pilgrim flask (1626-27; museum number: 1950,1019.1) is grouped with several pieces of Ming porcelain and their ceramic imitations made in Mamluk Egypt (1250-1517), Ottoman Turkey (1299-1923), Safavid Iran and Mughal India.

The placement of the Ming pilgrim flask in the showcase Cultural Interactions in the South Asian section of Gallery 33, like the one put in the Chinese section described above, indicates the idea of cultural exchange: it reflects the close relationship between China and India under the Mughal emperors. Before the refurbishment, the old South-Asian section of Gallery 33 mainly displayed religious sculptures, which could generate a misunderstanding or cultural stereotype, as if the culture of South Asia is confined to religious life. Following the gallery renovation, the South Asia section of Gallery 33 now incorporates more diverse objects, not only those made in India; the display of the pieces of Ming-Qing porcelain is exemplary of this. In the showcase Cultural Interactions, the Ming pilgrim flask (museum number: 1968,0422.32) is juxtaposed with a Qing water pipe commissioned by Indian patrons (museum number: 1956,1017.2) and a Ming cloisonné ewer with an Indian-inspired shape (museum number: 1990,0411.1). ${ }^{17}$ Also found in this showcase are shards of Ming porcelain from Gaur, one Indian city where Chinese officials from the Ming court were greeted (museum number: 2005.0813.1.1-12). ${ }^{18}$ The label calls the pilgrim flask 'Emperor Aurangzeb's moonflask', placing emphasis on ownership:

This Chinese moon-flask belonged to the Mughal Emperor Aurangzeb (ruled 16581707). His name is inscribed at the bottom with the date 1660, the second year of his rule. The flask may have reached him through trade or as a diplomatic gift. 
The identification of Mughal Emperor Aurangzeb as owner indicates a process of identitytransformation that Ming porcelain underwent in Mughal India. In the words of the art historian Stacey Pierson, the flask 'is no longer a "Chinese" object in the possessive sense but rather an Indian object of Chinese origin' (Pierson 2013: 39). Such a change of identity in terms of ownership, however, becomes unobtrusive, as the Aurangzeb inscription - the mark of personal ownership - on the bottom of the flask is hidden from view by its arrangement.

The Mughal Empire witnessed the prosperity and decline of Ming China and went on to witness the thriving of European maritime powers, with their ambitious schemes for trade and colonization. The Portuguese were the first navigators to sail directly to India from Europe, and then settled in Goa, Malacca, and Macao. From these places, tons of Chinese porcelain were transported to Lisbon. In 1571, the Spaniards established their headquarters in Manila, on the west coast of the Philippines, where South American silver was transported in exchange for Chinese silk, cotton, and porcelain. The Netherlands greeted their Golden Age in the seventeenth century, a greeting that coincides with the founding of the Dutch East India Company (the VOC, founded in 1602). Throughout the first half of the seventeenth century, more than three million pieces of Chinese porcelain were transported from Batavia, the Company's headquarters in Asia, to Amsterdam (Volker 1954). The English East India Company (the EIC, founded in 1600) thereafter took over the VOC to become the dominant maritime power in the eighteenth century. During the so-called first global age (from the end of the fifteenth century to the end of the eighteenth century), sails and charts of Europeans progressively spread wherever profits called. On this grand stage of history, a late Ming pilgrim flask travelled far across the oceans, and it is now on view in Gallery 46 Europe 1400-1800 of the British Museum.

Gallery 46 Europe 1400-1800 aims to show how encounters with America and Asia generated profound social changes and artistic developments in Europe. To speak specifically of the massive wall case where a piece of late-Ming pilgrim flask (Wanli period, 1590-1620; museum number: Franks.778.+) is on display, it reveals how European trading companies acted as go-betweens, reshaping the European worldview through contacting, and consuming, Others..$^{19}$ Groups of objects in this wall case are organized into four bays, each with a thematic topic: Northern Sea Trade; Impact of the East; Trade and Territory; and Distant Worlds Made Tangible. Since these four bays are separated only by thin sheets of glass, they seem more like a continuous story than four unconnected themes: from regional maritime commerce to overseas trade, and then back to the domestic context to show how the vast distances between Europe and the outside world were compressed by collecting. The Ming pilgrim flask is placed in the second bay, Impact of the East. Considered in association with the other objects displayed in the wall case, the Ming flask is readily identified as a possession of Europeans, or to use Russell Belk's (1988) words, the Ming flask is an 'extended self' of Europeans.

According to Belk, the concept of 'extended self' entails 'not only that which is seen as "me" (the self), but also that which is seen as "mine"' (Belk 1988: 140). ${ }^{20}$ To possess an object means to invest our time, efforts, and attention in it, and these investments transform it into property that can serve to fashion a desirable self-image. The concept of 'extended self' enables one to define who one is by what one possesses. This is not limited to the individual dimension, but extends to 'a hierarchical arrangement of levels of self, because we exist not only as individuals, but also as collectivities' (Belk 1988: 152). For the present discussion of how this Ming pilgrim flask is displayed in a way that makes it an aspect of 'extended self' for Europeans, two levels of Self can be identified: individual (Philip II, King of Spain and Portugal, ruled 1556-98) and cultural group (the European traders in the seventeenth and eighteenth centuries, especially the English, Dutch, Spanish, and Portuguese). Which level of Self is identified depends on which vantage point is selected to view the Ming flask and its relations to the other materials on display.

To start off, let us focus on the Ming flask. In the second bay, Impact of the East, the flask is combined with other Chinese and Indian products made for the European markets, including a Ming kraak porcelain dish (museum number: Franks.275.+) and two seventeenthcentury Indian candlesticks (museum number: OA+2643, 1-2), and some pieces of Dutch and British earthenware in Chinese-style to exemplify the 'Oriental mania' in seventeenthcentury Europe, as is indicated by the text panel. ${ }^{21}$ Compared to the Ming flasks displayed 
in the Chinese and Indian sections of Gallery 33 that I discussed above, this Ming flask has a particularly tall neck and its foot is trapezoidal. Its unique shape is considered to be inspired by a metal prototype from the Islamic world, like, for example, the brass pilgrim flask discovered in the Indian provinces of the Ghurid empire (around 879-1215), now on display in the British Museum's Gallery 42 The Islamic World (museum number: 1883,1019.7) (Pinto de Matos 2016: 106). ${ }^{22}$

The way that the Ming flask is arranged further shifts our attention from its Chinese origin to its European ownership. The side facing towards visitors is decorated with a Spanish coat of arms showing lions and castles, which is, according to the label, copied from coins minted during the reign of Philip II. The pattern on the other side of the flask, a landscape with a seated Chinese scholar and his servant boy, is neither visible nor mentioned. As it was a personalized product and token of status of King Philip II, this Chinese flask can be re-identified and appropriated as Spanish/European, and is now categorized in the British Museum based on its location of consumption.

Standing a few paces away from the wall case, we can associate the Ming pilgrim flask with the objects displayed in the third bay, Trade and Territory, the former seems to become a cartographic tool that situates the European sense of Self by mapping the European sphere of influence across the globe. The group of objects in the third bay maps out the overseas commercial circuit connecting Europe to America and Asia during the seventeenth and eighteenth centuries. There is, to name just a few objects, a Qing porcelain garniture set (museum number: 1992,0605.1-5); a Ming bowl excavated from a Chinese junk wrecked in the South China Sea (ca. 1643; museum number: 1985,1119.33); a globe-shaped German cup engraved with a world map (museum number: 1998,0201.1); a Dutch wine glass engraved with a sailing ship (museum number: 1890,0209.4); and eight silver reales minted in Peru under the reign of the Spanish King Philip II (museum number: 1935,0401.10304), showing castles and lions just like the coat of arms on the Ming flask. ${ }^{23}$ The Ming flask can be seen in combination with these objects, as it was also a trade good with exchange value. Together, they suggest a sense of domination: the possession of objects from foreign lands and other cultures is a powerful assertion of national authority that expands beyond national boundaries (Macdonald 2003: 3).

If we step away a bit further, the Ming flask can also be seen together with the objects in the fourth and final bay, Distant Worlds Made Tangible. With engraved gems and motherof-pearl, and metal-mounted vessels made of coral, ivory, amber, and coconut, this part of the display recalls the archetypal 'cabinet of curiosities', in which the microcosm corresponds to the macrocosm. The text panel reads:

The discovery of the New World and the development of contacts with Africa and the Far East revolutionized the way in which the world was perceived. The Natural World, as studied by Renaissance scientists, now encompassed rarities from exotic lands. Such rarities, whether natural (a coconut shell), or artificial (a Chinese porcelain bowl), were often mounted in silver and gold.

Organizing, categorizing, and mounting material collections, the cabinet of curiosities embodied a logic Europeans used to mirror the wider world in a 'miniature version of the universe' (Pomian 1990[1987]: 69). It mediates the interrelation between binaries such as natural and artefactual, distance and intimacy, overseas and domestic, and intangible and tangible. The cabinet of curiosities to which this fourth bay of the wall case refers is both a material constitution and symbolic expression of what the anthropologist James Clifford calls 'a world of value' (Clifford 1988: 220; emphasis in original).

The picture, The Yarmouth Collection (ca. 1665, also known as The Paston Treasures), featured with the Distant Worlds Made Tangible bay text panel is also noteworthy, as it potentially secures a European sense of Self in terms of possession. ${ }^{24}$ This Dutch still life depicts a panoply of valuables assembled by the Paston family of Norfolk, in the United Kingdom. In the central foreground is a singing girl who is surrounded by objects both natural and artefactual. These objects include, just to name a few: a Chinese porcelain kraak dish filled with a pink lobster, roses and fruits; a silver-gilt flagon decorated with shells; a monkey; a clock; and an enslaved person probably owned by the Pastons. ${ }^{25}$ Intangible geographical 
distances are compressed by these tangible things crowded into an interior scene. The anthropologist David Howes refers to this painting as 'an empire of the senses constituted by the best the world has to offer' (Howes 2005: 13). What is more, the sensory empire here is equally 'a political empire':

Rich and rare sensations have been brought together from all over the world (as is suggested by the presence of the globe). Not just artefacts and plants, but also animals and humans form part of this empire. [...] We see here that everything has been displaced from its original setting and brought together to form a new world order (Howes 2005: 13).

Featuring this still life with the Distant Worlds Made Tangible bay text panel may contribute to securing the European ownership of the objects placed in this bay and, more broadly speaking, in this wall case, including the Ming pilgrim flask. Or, put differently, the objects on display in this wall case are potentially transformed into components of a sensory/political empire that is built upon the European ownership and accumulation of objects from around the world.

Using the phrase Distant Worlds Made Tangible, and the ideas evoked by this phrase, as a kind of closing remark in the wall case is equally suggestive. Conceivably, the phrase encourages an affiliation with the displays in the previous two bays, Impact of the East and Trade and Territory, and in this way a continuous storyline unfolds in parallel with a flow of material goods: exotic commodities transported along trade routes towards Europe, where their tangible presence evoked overseas voyages and experiences of exploration; they might then be purchased, gifted, or collected in a domestic cabinet, wherein they were possessed and appropriated as a way for Europeans to map and grasp the world. Arguably, the arrangement in the wall case reveals an 'object biographical' approach to display, through which the identitytransformation of the objects, such as the Ming pilgrim flask, is traceable.

Tracing the trans-border arrangement of Ming porcelain in the British Museum's Asian and European galleries, walking past its combination of various objects, replicates in our act the dissemination of Ming porcelain on an interregional scale (in Eurasia). This reenactment, one that underscores the fruitfulness of perceiving the cultural-geographical boundaries that the gallery walls represent as porous, would have been hard to imagine just a few decades ago. Based on his curatorial experience in the Victoria and Albert Museum in London in the 1980s, the art historian Craig Clunas (2006) points out that it would have inevitably aroused disputes if an object were not displayed according to its provenance. For example, Chinese objects would not have been placed in the Japanese gallery, and no European products would have been found in the gallery of the Middle East - no matter how closely interconnected these regions have been for thousands of years via transfers of people and materials. However, such a production-based categorization of museum collections has been called into question in both academia and curatorial practices in the wake of the global turn in art history.

\section{Boundaries in Question: The Global Turn in Art History and Transcultural Presentation in the Museum Space}

The word 'global' in the global turn in art history generally refers to a pluralistic transcultural perspective rather than a comprehensive geographical scope. ${ }^{26} \mathrm{Here}$, I tend not to take the historian Bruce Mazlish's use of the term 'global history' to refer primarily to 'the history of globalization' in 'a new global epoch' emerging roughly after the 1970s (Mazlish 1998: 3901). Following this idea confines global (art) history to a contemporary development. Rather, I draw on the explanation of the historian Sebastian Conrad, who considers global history not as a synonym for macro-history or the history of globalization, but as a perspective, or more specifically, 'a heuristic device that allows the historian to pose questions and generate answers that are different from those created by other approaches' (Conrad 2016: 11, 72). As Conrad reminds us, the term 'global' does not necessarily mean the de-bordered, 'planetary totality of historical processes', but can also entail an approach that helps move beyond and reflect on established frameworks in the narrative of history (Conrad 2016: 95). Understanding global as a research lens promises a particular way of looking at (art) history that focuses on dynamic processes of connection, circulation, and transformation and thereby breaks out of 
compartmental thinking about cultures which is rooted in nationalism and the Eurocentric binary of Us and Others. ${ }^{27}$

This reading of 'global' is aligned with the 'notion of globality informed by a transcultural perspective' that Monica Juneja proposes (Juneja 2018: 480). A transcultural perspective, according to Juneja, 'works to re-define the units of art history, away from national frames and following the logic of the movement of agents, objects and practices' (Juneja 2018: 480). ${ }^{28}$ From such a perspective, the global turn in art history opens up important questions about the validity of the preexisting categories into which the discipline has long been sorted. Could the discipline of art history be restructured in ways that move beyond such monolithic categories as period styles, empires, and nation-states and towards the historical-spatial networks underpinning ongoing patterns of cultural interaction? Could the history of art and material culture be organized by a de-territorialized, rather than a centre-periphery model? How does a rethinking of the essentializing frames of art historical narratives help to unravel the possible ideological texture of the discipline?

These questions reveal how rethinking art history from a global/transcultural perspective often entails critical self-reflection on the ways the discipline has been constructed. Along the same lines, it often entails challenging static, homogeneous, and bounded ideas of culture. 'We cannot', as the art historian Kitty Zijlmans points out, 'unwrite the art history that has been written [...] What we can do, and what has been happening for the past decade, is to reevaluate how art history has been written and question why it happened in such a way' (Zijlmans 2007: 293). To do so, we need to unsettle the existing cultural and regional framing of art historical writing, 'of its methods and descriptions of in- and exclusion' (Zijlmans 2008: 149). Importantly, the purpose of rethinking the disciplinary frame of art history is not to eliminate all forms of boundaries entirely, but to take all boundary conditions as a subject of investigation, rather than as a given fact. For the art historian Claire Farago, this means that we need to treat all boundary conditions as 'porous and double-sided, strategically invested rather than natural or inevitable constructs' (Farago 2017: 307). To think of cultural boundaries as porous rather than self-contained involves a shift in emphasis from vertical influence to horizontal circulation. The study of artistic influence or diffusion is considered increasingly inadequate in light of the global turn in art history, as it is often based on a central-peripheral structure of thought. ${ }^{29} \mathrm{By}$ contrast, viewing circulation as 'a motor of transformation', as Juneja does, enables one to perceive an object's meaning as accumulating and transforming along with its displacement across points of production, exchange, and consumption (Juneja 2015: 60-1). Hence, a key part of approaching art history from a global/transcultural perspective is acknowledging the life history and alterity of an object, an object whose identity formation needs to be explored from multiple perspectives. The trans-border arrangement of the Ming pilgrim flasks in the British Museum provides a promising example to demonstrate how museum presentation can explore and redraw the existing boundaries of art-historical categorization through the application of a transcultural perspective.

There are, of course, other ways for a museum to challenge homogeneous, bounded ideas of culture and cultural identity. The museum world today has seen efforts at spatial reorganization and collection re-contextualization, attempts to reflect on the existing modes of display and categorization. An interesting example is the research project Objects in Transfer (2012-2016), at the Museum für Islamische Kunst (Museum of Islamic Art) in Berlin, which has been practised in the semi-permanent display of the museum since 2016. The idea of transculturation and its impact on unsettling the rigid cultural boundaries endorsed by the exclusive categories of museums is central to the project. The art historian Vera Beyer, who was the head of Objects in Transfer, points out: 'We have explored connections and transfers of objects that are transcultural in the sense that they undermine current cultural categories - in this case that of Islamic art' (Beyer 2016: 14-5). For objects with biographical trajectories crossing different cultural regions, the umbrella term 'Islamic Art' - a religious category combined with the European concept of art - is obviously inadequate, because it constitutes 'a process of delimitation of Christian from Islamic culture' (Beyer 2016: 13). ${ }^{30}$ To enable audiences to trace the transfer of the selected objects, a number of interactive installations are embedded in the galleries, including touchscreens, and a digital platform accessed through QR codes. There are also floor arrows pointing toward related objects 
housed in two other museums in Berlin, the Deutsches Historisches Museum (German Historical Museum) and the Museum für Byzantinische Kunst (Museum of Byzantine Art), where similar arrows point back in return. Such cross-references further encourage a tracing of cultural interaction beyond the limits of museum walls.

Another promising strategy for (art) historians and curators to transcend a narrowly national perspective is to work within larger interregional spaces, such as the seas and oceans which are filigreed with interregional trading networks (Conrad 2016: 118-20). For example, between 2014 and 2015, the British Museum hosted the special exhibition Connecting Continents: Indian Ocean Trade and Exchange. This small exhibition presents objects from the museum's collection that cross cultural boundaries. Interregional maritime spaces are indeed a logical framework for museums to tell stories regarding cultural connection and exchange. However, as mentioned, this does not necessarily mean that the dominant categories in the British Museum's semi-permanent display have to be entirely abolished. Even in moving away from monolithic ideas of culture, Claire Farago reminds us of the practical advantage of retaining enough of art history's existing categories: that is, 'to allow our archives, our databases, and our professional modes of being in the world to continue to function in recognizable ways' (Farago 2010: 18). Indeed, for such institutions as the British Museum, which presents a world-spanning collection, a cultural-geographical framework is still immediately graspable. My point here is that, through deploying a transcultural perspective in its object arrangement, the museum is capable of representing material circulations that transcend existing borderlines.

The trans-border arrangement of the Ming porcelain flasks analyzed above shows the potential for the museum to be a place where different narrative frameworks (chronological and synchronic, cultural and transcultural) can coexist and complement each other. Such coexistence can help tell more dynamic stories of cultural connection and enable a more dynamic reading of its collections. The British Museum's rich collection from around the world makes it pertinent for reflecting on the prevailing cultural boundaries embodied in museum categories. The present museum director, Hartwig Fischer, has set out a vision for the next decade: building a more cohesive historical narrative between galleries to show more coherence between cultures. ${ }^{31}$ This vision shows a promise of thawing binary sets of oppositions with more emphasis on forms of interactions across cultural and regional boundaries. Nevertheless, the trans-border arrangement in the museum is currently quite challenging for audiences to trace, or even to notice, because of the lack of clear instructions. Given this, perhaps the museum can organize an exhibition trail which casts a transcultural perspective on the objects on display. There are a number of object trails accompanied by leaflets that already incorporate galleries in the British Museum: around the themes of, for example, empire and colonial exploitation, and LGBTQ history. ${ }^{32}$ Conceivably, if there is a transcultural exhibition trail with selected objects with global biographies (e.g. Ming pilgrim flasks) acting as 'gateways' to a culturally entangled world, a visit to the British Museum can potentially become a voyage towards a transcultural outlook. ${ }^{33}$

\section{Conclusion}

As a display scheme underpinned by the concepts of object biographies and transculturation, trans-border arrangement in museum space calls attention to the fluid and plural identities that an object might have accumulated throughout its life history. It highlights the inadequacy of framing an object based merely on its place of origin and shows the possible convergence of multiple narratives and spatial properties in one museum. What we have seen regarding the Ming pilgrim flasks in their trans-border arrangement in the British Museum is how such a display scheme can foreground cross-fertilization between regions. In this sense, transborder arrangement and the accompanying narrative of transculturation can aptly approach, if not actualize, one of the main objectives of the British Museum today: that is, to become a place to communicate that, to quote Fischer, 'human history was driven and has always been driven by exchange, by cultures communicating'. ${ }^{34}$

Received: 4 December 2019

Finally accepted: 2 December 2020 


\section{Notes}

1 See Mark Brown, 'British Museum to Bring Back Reading Room as Part of Revamp', The Guardian 4 July 2017. https://www.theguardian.com/culture/2017/ jul/04/british-museum-to-bring-back-reading-room-as-part-of-revamp, accessed 19 October 2020.

2 See John-Paul Stonard, 'How Hartwig Fischer plans to transform the British Museum', APOLLO 13 September 2017. https://www.apollo-magazine.com/howhartwig-fischer-plans-to-transform-the-british-museum/, accessed 19 October 2020.

3 The proposition of critically reflecting on national compartmentalization and the nationalist understandings of art historical styles was developed in the Germanspeaking scholarship around the turn of the twentieth century. However, partly because of growing German nationalism between the World Wars, this nonnationalist approach to art history lacked success. See Pfisterer 2008.

4 I will not delve into the British Museum's digital space built in such online platforms as Google Arts and Cultures, as it is beyond the scope of this article.

5 For Ortiz, the word 'transculturation' also highlights the 'the loss or uprooting of a previous culture [and] the consequent creation of new cultural phenomena'. He refers to the former as a process of 'deculturation' and the latter as 'neoculturation'. See Ortiz 1970[1940]: 102-3.

6 For a critical take on Wolfgang Welsch's development of transculturation/ transculturality, see Juneja and Kravagna 2013.

7 See Mariachiara Gasparini, 'Interview with Monica Juneja about Global Art History', TRAFO 29 January 2014. https://trafo.hypotheses.org/567, accessed 19 October 2020.

8 See Mariachiara Gasparini, 'Interview with Monica Juneja about Global Art History'.

9 An example Juneja provides here is Picasso's Guernica (1937). The painting is displayed at the Museo Reina Museum in Madrid but without reference to a conventional art-historical framework, such as genre. Rather, it is combined with works of different materials (e.g. magazines, sketches, and posters) from the same historical moment to make visible a wider web of cultural connections between these works and Latin America. See Juneja 2018: 479.

10 The trans-border arrangement of Ming pilgrim flasks as analyzed in this article is based on my personal visit to the British Museum on 21 April 2019.

11 See the British Museum's online collection: https://www.britishmuseum.org/ collection/object/A 1936-1012-243, accessed 19 October 2020.

12 See the British Museum's online collection: https://www.britishmuseum.org/ collection/object/A 1947-0712-325; and https://www.britishmuseum.org/collection/ object/W 1950-1019-1, accessed 19 October 2020.

13 For details about the renovation of Gallery 33 China and South Asia, see Portal 2017. The refurbishment of Galleries 42-43 The Islamic World was supported by the Albukhary Foundation, and they are now intentionally located adjacent to the European galleries, which provides 'the connections between the cultures of Islam [...] and the cultures of the Mediterranean World and Europe'. See the press release 'New Albukhary Foundation Gallery of the Islamic World to open 
in 2018' via artdaily: https://artdaily.cc/news/77408/British-Museum-announcesnew-Albukhary-Foundation-Gallery-of-the-Islamic-World-to-open-in-2018\#. X7Kt72hKiUk, accessed 19 October, 2020.

14 See the British Museum's online collection: https://www.britishmuseum.org/ collection/object/A 1947-0712-325; and https://www.britishmuseum.org/collection/ object/A_1968-0422-32, accessed 19 October 2020.

15 Commanded by the Chinese mariner and diplomat Zheng He (1371-1433/35), these seven maritime expeditions helped to revitalize the Sinocentric tribute system. The voyages reached as far west as the coast of East Africa. By acknowledging Ming China's superior position, these tributaries not only acquired guarantees of peace but also benefited from commercial transactions.

16 Horse with Chinese Grooms is a double-paged painting from the Bahram Mirza album (assembled 1544-1545), now collected in the Topkapi Museum in Istanbul. Royal Feast in a Garden is an illustration from the Shahnama (Book of Kings) of Firdausi (about 934-1020), now collected in the Cleveland Museum of Art, museum number: 1956.10.a.

17 See the British Museum's online collection: https://www.britishmuseum.org/ collection/object/A 1956-1017-2; and https://www.britishmuseum.org/collection/ object/A 1990-0411-1, accessed 19 October 2020.

18 See the British Museum's online collection: https://www.britishmuseum.org/ collection/object/A_2005-0813-1-1-64, accessed 19 October 2020.

19 See the British Museum's online collection: https://www.britishmuseum.org/ collection/object/A Franks-778-, accessed 19 October 2020.

20 Emerging in the seventeenth century, property became a central way for Europeans to conceptualize an ideal selfhood, and this mode of conceptualization was facilitated by the expansion of trading networks. See Macpherson 1962.

21 See the British Museum's online collection: https://www.britishmuseum.org/ collection/object/A Franks-275-; https://www.britishmuseum.org/collection/ object/W OA-2643-1-2, accessed 19 October 2020. Kraak porcelain, a type of Chinese export porcelain mainly decorated in underglaze cobalt blue, was made in large quantities in the late Ming dynasty. Kraak is thought to be named after Portuguese ships known as carracks.

22 See the British Museum's online collection: https://www.britishmuseum.org/ collection/object/W 1883-1019-7, accessed 19 October 2020.

23 See the British Museum's online collection: https://www.britishmuseum. org/collection/object/A 1992-0605-1-5; https://www.britishmuseum. org/collection/object/A 1985-1119-33; https://www.britishmuseum.org/ collection/object/H 1998-0201-1 1; https://www.britishmuseum.org/ collection/object/H 1890-0209-4; https://www.britishmuseum.org/collection/ object/C 1935-0401-10304, accessed 19 October 2020.

24 The Yarmouth Collection is now collected in the Norwich Castle Museum and Art Gallery, accession number: NWHCM: 1947.170.

25 For a detailed survey of the symbolic meanings of the objects in The Yarmouth Collection, see Wenley 1991. 
See Mariachiara Gasparini, 'Interview with Monica Juneja about Global Art History'.

The global turn in art history not only seeks approaches to transcend the conventional boundaries of categorization. It also calls for enhancing interdisciplinary cooperation. See Zijlmans 2003: 203.

See also Mariachiara Gasparini, 'Interview with Monica Juneja about Global Art History'.

29 For more about the difference between studies of diffusion or influence and studies of continuing circulations without implications of cultural hierarchies, see Kaufmann et al., 2015: 2-3.

30 For example, there is a carved ivory horn made between the eleventh and twelfth centuries, collected by the Museum für Islamische Kunst and also part of the project Objects in Transfer. It cannot be assigned to a single place of origin as it circulated throughout the medieval Mediterranean and thus embodies shared Islamic and Byzantine tastes (Dolezalek 2016).

31 See Charlotte Higgins, 'Interview British Museum Director Hartwig Fischer: "There are no foreigners here - the museum is a world country"', The Guardian 13 April 2018. https://www.theguardian.com/culture/2018/apr/13/british-museum-directorhartwig-fischer-there-are-no-foreigners-here-the-museum-is-a-world-country, accessed 19 October 2020.

32 For the object trails in the British Museum today, see: https://www.britishmuseum. org/visit/object-trails, accessed 19 October 2020.

33 The word 'gateway' here is used on purpose in order to evoke the idea of 'gateway objects' which the British Museum adopted in 2006 to structure a more comprehensible interpretative model in its semi-permanent galleries. Gateway objects refer to a group of carefully chosen objects that act as gateways to larger themes. They are usually arranged in a way that can effectively grab audiences' attention - for example, in the centre of a display case or at the entrance of a gallery - in order to tell an overarching story of that showcase or that gallery. The gateway objects approach was proposed by the British Museum's interpretation team, established in 2005. See Batty et al. 2016.

34 See Charlotte Higgins, 'Interview British Museum Director Hartwig Fischer'.

\section{References}

Alberti, S.J.M.M. (2005) ‘Objects and the Museum’, Isis, 96 (4) 559-71.

Appadurai, A. (ed) (1986) The Social Life of Things: Commodities in Cultural Perspective, Cambridge: Cambridge University Press.

Batty, J., Carr, J., Edwards, C., Francis, D., Frost, S., Miles, E. and Penrose, R. (2016)

'Object-Focused Text at the British Museum', Exhibition, 36 (1) 70-80.

Beier-de Haan, R. (2006) 'Re-staging Histories and Identities', in Sharon Macdonald (ed) A Companion to Museum Studies, 186-97, Oxford: Blackwell Publishing.

Belk, R.W. (1988) 'Possessions and the Extended Self', The Journal of Consumer Research, 15 (2) 139-68. 
Bennett, T. (1995) The Birth of the Museum: History, Theory, Politics, London and New York: Routledge.

Beyer, V. (2016) 'Beyond the Museum Walls. Questioning the Cultural Delimitation of "Islamic Art" by Pointing to the Entanglement of Collections', in Vera Beyer, Isabelle Dolezalek and Sophia Vassilopoulou (eds) Objects in Transfer: A Transcultural Exhibition Trail through the Museum für Islamische Kunst in Berlin, 13-24, Berlin: Museum für Islamische Kunst. Online at: http://www.objects-in-transfer.sfbepisteme.de/document/Objects\%20in\%20Transfer.pdf.

Clifford, J. (1988) The Predicament of Culture: Twentieth-Century Ethnography, Literature, and Art, Cambridge: Harvard University Press.

Clunas, C. (2006) 'Wuzhi wenhua-zai dongxi eryuanlun zhi wai' 物質文化一在東西二 元論之外 [Material Culture Beyond the East/West Binary], translated by Liao Yi-Fang, Xin Shixue 新史學 [New History], 17 (4) 195-215.

Conrad, S. (2016) What is Global History?, Princeton and Oxford: Princeton University Press.

Dolezalek, I. (2016) 'Alternative Narratives. Transcultural Interventions in the Permanent Display of the Museum für Islamische Kunst', in Vera Beyer, Isabelle Dolezalek and Sophia Vassilopoulou (eds) Objects in Transfer: A Transcultural Exhibition Trail through the Museum für Islamische Kunst in Berlin, 25-35, Berlin: Museum für Islamische Kunst. Online at: http://www. objects-in-transfer.sfb-episteme.de/document/Objects\%20in\%20Transfer. pdf.

Farago, C. (2010) 'On the Peripatetic Life of Objects in the Era of Globalization', in Mary D. Sheriff (ed) Cultural Contact and the Making of European Art Since the Age of Exploration, 17-42, Chapel Hill: The University of North Carolina Press.

(2017) 'The 'Global Turn' in Art History: Why, When, and How Does It Matter?', in Daniel Savoy (ed) The Globalization of Renaissance Art: A Critical Review, 299-313, Leiden; Boston: Brill.

Finlay, R. (1998) 'The Pilgrim Art: The Culture of Porcelain in World History', Journal of World History, 9 (2) 141-87.

(2010) The Pilgrim Art: Cultures of Porcelain in World History, Berkeley, Los Angeles, and London: University of California Press.

Gerritsen, A. and Riello, G. (eds) (2016) The Global Lives of Things: The Material Culture of Connection in the Early Modern World, London and New York: Routledge.

Gosden, C. and Marshall, Y. (1999) 'The Cultural Biography of Objects', World Archaeology, 31 (2) 169-78.

Hill, K. (ed) (2012) Museums and Biographies: Stories, Objects, Identities, London: Boydell and Brewer.

Howes, D. (2005) Empire of the Senses: The Sensual Culture Reader, Oxford: Berg.

Juneja, M. (2015) 'Circulation and Beyond - The Trajectories of Vision in Early Modern Eurasia', in Thomas DaCosta Kaufmann, Catherine Dossin and Béatrice JoyeuxPrunel (eds) Circulations in the Global History of Art, 59-77, Farnham and Burlington: Ashgate. 
(2018) "'A very civil idea..." Art History, Transculturation, and World-Making - With and Beyond the Nation', Zeitschrift für Kunstgeschichte, 81 (4) 461-85.

Juneja, M. and Grasskamp, A. (2018) 'EurAsian Matters: An Introduction', in Anna Grasskamp and Monica Juneja (eds) EurAsian Matters: China, Europe, and the Transcultural Object, 1600-1800, 3-33, Cham: Springer.

Juneja, M. and Kravagna C. (2013) 'Understanding Transculturalism - Monica Juneja and Christian Kravagna in Conversation', in Model House Research Group (ed) Transcultural Modernisms, 22-33, Berlin: Sternberg Press.

Kaufmann, T.D., Dossin, C. and Joyeux-Prunel, B. (eds) (2015) Circulations in the Global History of Art, Farnham and Burlington: Ashgate.

Kopytoff, I. (1986) 'The Cultural Biography of Things: Commoditization as Process', in Arjun Appadurai (ed) The Social Life of Things: Commodities in Cultural Perspective, 64-91, Cambridge: Cambridge University Press.

Leidy, D.P. (2015) How to Read Chinese Ceramics, New York: The Metropolitan Museum of Art; New Heaven and London: Yale University Press.

Macdonald, S. (2003) 'Museums, National, Postnational and Transcultural Identities', Museum and Society, 1 (1) 1-16.

MacPherson, C.B. (1962) The Political Theory of Possessive Individualism, Oxford: Oxford University Press.

Martin, M. and Bleichmar, D. (2015) 'Introduction: Objects in Motion in the Early Modern World', Art History, 38 (4) 605-19.

Mason, R. (2013) 'National Museums, Globalization, and Postnationalism: Imaging a Cosmopolitan Museology', Museum Worlds: Advances in Research, 1 40-64.

Mazlish, B. (1998) 'Comparing Global History to World History', Journal of Interdisciplinary History, 28 (3) 385-95.

Ortiz, F. (1970[1940]) Cuban Counterpoint: Tobacco and Sugar, New York: Vintage Books.

Pfisterer, U. (2008) 'The Many Beginnings and the One End of World Art History in Germany, 1900-1933', in Kitty Zijlmans and Wilfrid van Damme (eds) World Art Studies: Exploring Concepts and Approaches, 69-89, Amsterdam: Valiz.

Pierson, S. (2013) From Object to Concept: Global Consumption and the Transformation of Ming Porcelain, Hong Kong: Hong Kong University Press.

Pinto de Matos, M.A. (2016) Global by Design: Chinese Ceramics from the R. Albuquerque Collection, London: Jorge Welsh Research \& Publishing.

Pomian, K. (1990[1987]) Collectors and Curiosities: Paris and Venice, 1500-1800, Cambridge: Polity Press.

Poovaya-Smith, N. (1998) 'Keys to the Magic Kingdom: The New Transcultural Collections of Bradford Art Galleries and Museums', in Tim Barringer and Tom Flynn (eds) Colonialism and the Object: Empire, Material Culture and the Museum, 111-25, London: Routledge.

Portal, J. (2017) 'Creating the New Sir Joseph Hotung Gallery of China and South Asia', Arts of Asia, 47 (6) 42-9. 
Sheriff, M.D. (2010) Cultural Contact and the Making of European Art Since the Age of Exploration, Chapel Hill: The University of North Carolina Press.

Volker T. (1954) Porcelain and the Dutch East India Company, Leiden: Brill.

Welsch, W. (1999) 'Transculturality: The Puzzling Form of Cultures Today', in Mike Featherstone and Scott Lash (eds) Spaces of Culture: City, Nation, World, 194-213, London: Sage.

(2001) 'Transculturality: The Changing Form of Cultures Today', Filozofski-vestnik, 22 (2) 59-86.

Wenley, R. (1991) 'Robert Paston and the Yarmouth Collection', Norfolk Archaeology, 41 (2) $113-44$.

Zijlmans, K. (2003) 'Pushing Back Frontiers: Towards a History of Art in a Global Perspective', International Journal of Anthropology, 18 (4) 201-10.

(2007) 'An Intercultural Perspective in Art History: Beyond Othering and Appropriation', in James Elkins (ed) Is Art History Global? 289-98, London and New York: Routledge.

(2008) 'The Discourse on Contemporary Art and the Globalization of the Art System', in Kitty Zijlmans and Wilfrid van Damme (eds) World Art Studies: Exploring Concepts and Approaches, 135-50, Amsterdam: Valiz.

\section{Author}

Pao-Yi Yang

ORCID iD: http://orcid.org/0000-0001-6734-2687

Leiden University Centre for the Arts in Society (LUCAS)

Netherlands

paoyiyangacl@gmail.com 